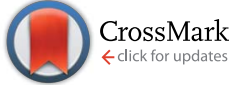

Cite this: RSC Adv., 2017, 7, 1056

Received 19th October 2016 Accepted 9th November 2016

DOI: $10.1039 / \mathrm{c} 6 \mathrm{ra} 25460 \mathrm{~h}$

www.rsc.org/advances

\section{Phosphoric acid doped hydrophobic ionic liquid- based composite membranes for anhydrous proton exchange membrane application}

\author{
Bencai Lin, ${ }^{\text {ab }}$ Gang Qiao, ${ }^{a}$ Fuqiang Chu, ${ }^{a}$ Shuai Zhang, ${ }^{a}$ Ningyi Yuan ${ }^{\text {ab }}$ \\ and Jianning Ding *abc
}

In this study, phosphoric acid doped hydrophobic ionic liquid-based composite membranes are successfully synthesized and characterized. 1-Vinyl-3-butylimidazolium bis(trifluoromethylsulfonyl)-imide ( $[\mathrm{VBIm}]\left[\mathrm{NTf}_{2}\right]$ ) was synthesized and used as hydrophobic phase in the composite membranes. The $\mathrm{H}_{3} \mathrm{PO}_{4}$ uptake of the composite membranes increases with the increasing content of $[\mathrm{VBIm}]\left[\mathrm{NTf}_{2}\right]$ and then decreases. The resultant composite membranes showed good thermal stability, mechanical properties and high proton conductivity (up to the order of $10^{-2} \mathrm{~S} \mathrm{~cm}^{-1}$ at $180{ }^{\circ} \mathrm{C}$ ) at high temperatures under anhydrous conditions. The results of this study suggest that this type of PEMs have good perspectives for high temperature proton exchange membrane fuel cell applications.

\section{Introduction}

Proton exchange membrane fuel cells (PEMFCs), which convert chemical energy directly to electrical energy and avoid the limitations of Carnot cycle, are considered as one of the most promising power generation technologies. ${ }^{1-3}$ Compared with the normal PEMFCs operations at low temperatures (below 90 ${ }^{\circ} \mathrm{C}$ ), the PEMFCs operating at elevated temperatures in the range of $120-200{ }^{\circ} \mathrm{C}$ under anhydrous conditions have several merits, including simplified heat and water management, increased fuel cell efficiency and improved catalyst tolerance to CO. ${ }^{4-6}$ However, typical proton exchange membranes (PEMs) such as DuPont's Nafion ${ }^{\circledR}$ membranes can hardly operate at elevated temperature range $\left(120-200{ }^{\circ} \mathrm{C}\right)$ due to the dehydration of membranes. ${ }^{7}$ Therefore, a critical challenge in developing high temperature PEMFCs is to develop low cost PEMs with high conductivity at elevated temperatures.

Recently, several studies have been conducted for the preparation of novel or functionalized commercially proton exchange membranes with good fuel cell performance at elevated temperatures. ${ }^{8-14}$ Development of sulfonated polymers with the sulfonic acid groups is an important approach to preserve water and obtain high temperature PEMs. ${ }^{15}$ Though high degree of sulfonation results in high proton conductivity of

${ }^{a}$ School of Materials Science and Engineering, Jiangsu Collaborative Innovation Center for Photovolatic Science and Engineering, Changzhou University, Changzhou, 213164, Jiangsu, China.E-mail: linbencai@cczu.edu.cn; dingjn@cczu.edu.cn

${ }^{b}$ Jiangsu Province Cultivation Base for State Key Laboratory of Photovoltaic Science and Technology, Changzhou University, Changzhou, 213164, Jiangsu, China

${ }^{c}$ Micro/Nano Science and Technology Center, Jiangsu University, Zhenjiang, 212013, China
PEMs, it also reduces the mechanical properties of membranes because of high swelling ratio. ${ }^{16}$ Both proton conductivity and mechanical properties of PEMs could be enhanced at elevated temperatures by adding hydrophilic inorganic additives into sulfonated polymers. ${ }^{17,18}$ However, this type of composite PEMs still cannot maintain high proton conductivity above $130{ }^{\circ} \mathrm{C}$ due to the evaporation of water. ${ }^{19}$

Phosphoric acid could be used as high temperature protonic conductors; it is an effective way to prepare high temperature PEMs by replacement of water with phosphoric acid. ${ }^{20-24}$ The dynamic hydrogen bond networks that formed from phosphoric acid, favor the transfer of protons. ${ }^{25,26}$ On the other hand, the incorporation of phosphoric acid could improve the water uptake of PEMs at high temperatures. ${ }^{27}$ Therefore, phosphoric acid doped PEMs have attracted much attention due to the high proton conductivity at elevated temperatures. Generally, more phosphoric acid uptake of the polymer systems leads to a higher conductivity of the membranes. However, too high phosphoric acid uptake of the PEMs often reduces the mechanical properties and chemical stabilities of the membranes significantly, ${ }^{28}$ making them unsuitable for practical use.

Recently, syntheses of new types of ionic polymers ${ }^{29,30}$ have been pursued to obtain PEMs with high proton conductivity and excellent mechanical properties. Si et al. ${ }^{29}$ prepared phosphoric acid doped cross-linked proton-conducting membranes, and the resultant composite membranes showed high thermal stability and high proton conductivity (at $160^{\circ} \mathrm{C}$ ). However, the membranes showed a high phosphoric acid uptake, and the mechanical properties of the membranes were not satisfactory. Therefore, synthesis of novel PEMs with excellent chemical and mechanical stability as well as high proton conductivity at high temperature is in great demand. 
Yan et al. reported novel composite PEMs by doping protic ionic liquid into the membranes, and the composite membranes showed good mechanical properties and high proton conductivity due to the microscopic phase separation formed in the membranes. ${ }^{19}$ It is usually considered that membranes with a well-defined phase separation morphology show higher conductivity and mechanical properties than those without microscopic phase separation structure. ${ }^{31}$ In the present study, a hydrophobic ionic liquid, 1-vinyl-3butylimidazolium bis(trifluoromethylsulfonyl)-imide, was synthesized and used for the preparation of high-temperature PEMs. A microscopic phase separation morphology is expected to be formed in the membranes due to the presence of a hydrophobic ionic liquid and phosphoric acid. The effect of the hydrophobic ionic liquid content on the membrane properties, such as thermal stability, mechanical properties, phosphoric acid uptake, swelling ratio, microstructure and proton conductivity, were systematically investigated.

\section{Experimental}

\section{Materials}

Styrene, acrylonitrile, $N$-vinylimidazole, divinylbenzene (DVB), benzoin ethyl ether, 1-bromobutane, ethyl acetate and bistrifluoromethanesulfonimide lithium salt were used as purchased. All of the vinyl monomers were made inhibitor-free by passing the liquid through a column filled with basic $\mathrm{Al}_{2} \mathrm{O}_{3}$ to remove the polymerization inhibitor. Distilled deionized water was used for all experiments.

\section{Synthesis of 1-vinyl-3-butylimidazolium bromide ([VBIm][Br])}

1-Vinyl-3-butylimidazolium bromide ([VBIm][Br]) was synthesized as documented in previous literature..$^{32}$ Briefly, a mixture of $N$-vinylimidazole $(4.70 \mathrm{~g}, 50 \mathrm{mmol})$ and 1-bromobutane ( $6.85 \mathrm{~g}, 50 \mathrm{mmol}$ ) was stirred at room temperature for $24 \mathrm{~h}$ under a nitrogen atmosphere. The product was washed three times with diethyl ether and ethyl acetate and then dried under dynamic vacuum. Yield: $95 \% .{ }^{1} \mathrm{H}$ NMR $\left(400 \mathrm{MHz}, \mathrm{CDCl}_{3}\right): 10.89$ (s, 1H), $7.86(\mathrm{~s}, 1 \mathrm{H}), 7.58(\mathrm{~s}, 1 \mathrm{H}), 7.52-7.44(\mathrm{~m}, 1 \mathrm{H}), 6.01-5.95$ (dd, 1H), 5.40-5.36 (dd, 1H), 4.43-4.38 (t, 2H), 1.97-1.87 (q, 2H), 1.44-1.32 (s, 2H), 0.97-0.92 (t, 3H).

\section{Synthesis of 1-vinyl-3-butylimidazolium bis(trifluoromethylsulfonyl)-imide ([VBIm] [NTf $\left.{ }_{2}\right]$ )}

1-Vinyl-3-butylimidazolium bis(trifluoromethylsulfonyl)-imide ([VBIm] [NTf $\left.{ }_{2}\right]$ ) was synthesized as follows (Scheme 1A): a solution of bistrifluoromethanesulfonimide lithium salt (15.79 g, 55 $\mathrm{mmol})$ and $[\mathrm{VBIm}][\mathrm{Br}](11.55 \mathrm{~g}, 50 \mathrm{mmol})$ in $50 \mathrm{~mL}$ water was stirred at room temperature for $12 \mathrm{~h}$. The resultant viscous oil was washed with deionized water three times and then dried under dynamic vacuum. Yield: $92 \% .{ }^{1} \mathrm{H}$ NMR $\left(400 \mathrm{MHz}, \mathrm{CDCl}_{3}\right)$ : $9.00(\mathrm{~S}, 1 \mathrm{H}), 7.65(\mathrm{~s}, 1 \mathrm{H}), 7.46(\mathrm{~s}, 1 \mathrm{H}), 7.17-7.09(\mathrm{~m}, 1 \mathrm{H}), 5.82-$ $5.76(\mathrm{dd}, 1 \mathrm{H}), 5.44-5.40(\mathrm{dd}, 1 \mathrm{H}), 4.25-4.30(\mathrm{t}, 2 \mathrm{H}), 1.92-1.82(\mathrm{q}$, 2H), 1.44-1.31 (m, 2H), 0.98-0.94 (t, 3H).

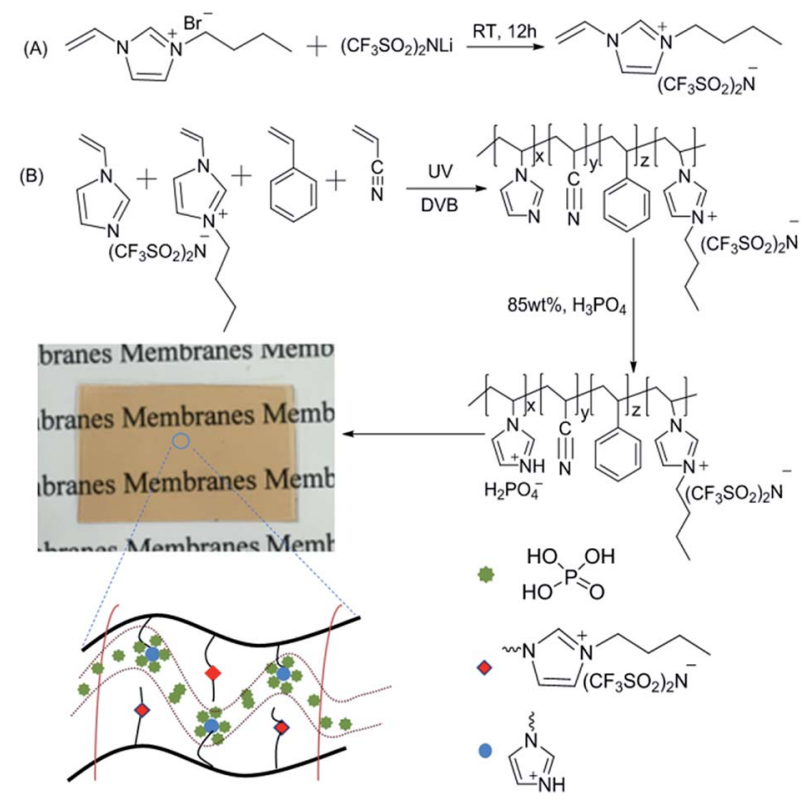

Scheme 1 Reaction scheme for the preparation of the phosphoric acid doped hydrophobic ionic liquid-based PEMs.

\section{Preparation of cross-linked phosphoric acid doped hydrophobic ionic liquid-based composite membranes}

The membranes were prepared as follows (Scheme 1B): to a mixture containing $0.30 \mathrm{~g}$ styrene/acrylonitrile (weight ratio, $1: 3), 0.04 \mathrm{~g}$ divinylbenzene and $0.02 \mathrm{~g}$ benzoin isobutyl ether in a glass bottle, $0.15 \mathrm{~g}$ [VBIm] $\left[\mathrm{NTf}_{2}\right]$ and $0.55 \mathrm{~g} N$-vinylimidazole were added and stirred to obtain a homogeneous oil. The mixture was cast into a glass mold and photo-cross-linked by irradiation with UV light of $250 \mathrm{~nm}$ wavelength for $30 \mathrm{~min}$ at room temperature (Scheme 1B). The prepared membranes were immersed in $85 \mathrm{wt} \%$ of $\mathrm{H}_{3} \mathrm{PO}_{4}$ solution at $80{ }^{\circ} \mathrm{C}$ for $24 \mathrm{~h}$. The acid-doped hydrophobic ionic liquid-based PEMs were wiped with filter paper and then dried in vacuum at $70^{\circ} \mathrm{C}$ for $36 \mathrm{~h}$, and the produced membranes were denoted as $[\mathrm{VBIm}]\left[\mathrm{NTf}_{2}\right]_{15^{-}}$ $\mathrm{VIm}_{55}$. In a similar way, a series of membranes, $[\mathrm{VBIm}]\left[\mathrm{NTf}_{2}\right]_{x^{-}}$ $\operatorname{VIm}_{y}$ ( $x$ and $y$ indicates the weight ratio of $[\operatorname{VBIm}]\left[\mathrm{NTf}_{2}\right]$ and $N$-vinylimidazole, respectively) was obtained by varying the weight ratio of $[\mathrm{VBIm}]\left[\mathrm{NTf}_{2}\right]$ and $N$-vinylimidazole in the membranes.

A mixture of styrene/acrylonitrile (weight ratio, $1: 3$, $30 \mathrm{wt} \%)$, [VBIm] [Bi] (15-55 wt\%), $N$-vinylimidazole (55-15 wt\%), divinylbenzene ( $4 \mathrm{wt} \%$ for the formulation based on the weight of monomer), and $2 \mathrm{wt} \%$ of photoinitiator benzoin isobutyl ether was stirred and ultrasonicated to obtain a homogeneous solution, which was then cast onto a glass mold and photocross-linked by irradiation with UV light of $250 \mathrm{~nm}$ wavelength at room temperature. The resultant membrane samples were washed with ethanol and distilled deionized water and vacuum dried at $120^{\circ} \mathrm{C}$ for $24 \mathrm{~h}$. The prepared membranes were soaked into $85 \mathrm{wt} \%$ of $\mathrm{H}_{3} \mathrm{PO}_{4}$ at $80{ }^{\circ} \mathrm{C}$ for $24 \mathrm{~h}$. The acid-doped membranes were wiped with filter paper and vacuum dried at $70{ }^{\circ} \mathrm{C}$ for $36 \mathrm{~h}$ to remove the absorbed water before characterization. 


\section{Characterization}

${ }^{1} \mathrm{H}$ NMR spectra were recorded on an AVANCE III $500 \mathrm{MHz}$ spectrometer. Fourier transform infrared (FT-IR) spectra of the polymers were recorded on a Nicolet Avatar 370 spectrometer in the range of $4000-400 \mathrm{~cm}^{-1}$. Thermal analysis was carried out by Netzsch 209 F3 thermogravimetric analyzer (TGA), and samples were heated from $30{ }^{\circ} \mathrm{C}$ to $600{ }^{\circ} \mathrm{C}$ at a heating rate of $10{ }^{\circ} \mathrm{C} \min ^{-1}$ under nitrogen flow. The tensile properties of the membranes were measured using an Instron Model 5 KN/WDT5 device at $25{ }^{\circ} \mathrm{C}$ at a crosshead speed of $5 \mathrm{~mm} \mathrm{~min}^{-1}$. Atomic force microscopy (AFM) images were obtained using an NTMDT Solver P47 in semicontact mode at room temperature.

\section{$\mathrm{H}_{3} \mathrm{PO}_{4}$ uptake and swelling ratio}

The membrane samples were soaked in $\mathrm{H}_{3} \mathrm{PO}_{4}$ at room temperature for $48 \mathrm{~h}$. The proton exchange membranes were removed from the vessel and excess $\mathrm{H}_{3} \mathrm{PO}_{4}$ on the surface was eliminated by wiping with a tissue paper and the sample was weighed immediately (denoted by the variable $W_{\mathrm{w}}$ ). The $\mathrm{H}_{3} \mathrm{PO}_{4}$ uptake $(W)$ was calculated with the following equation:

$$
W(\%)=\frac{\left(W_{\mathrm{w}}-W_{\mathrm{d}}\right)}{W_{\mathrm{d}}} \times 100 \%
$$

where $W_{\mathrm{w}}$ and $W_{\mathrm{d}}$ are the weight of the doped and undoped membranes, respectively.

The swelling ratio (SR) of the composite membranes was determined from the dimensional differences between the wet and dry samples. The calculation was based on the following equation:

$$
\operatorname{SR}(\%)=\frac{\left(L_{\mathrm{s}}-L_{\mathrm{d}}\right)}{L_{\mathrm{d}}} \times 100 \%
$$

where $L_{\mathrm{s}}$ and $L_{\mathrm{d}}$ are the lengths of the wet and dry membranes, respectively.

\section{Proton conductivity}

The resistance of the membrane samples was measured over the frequency range from $0.1 \mathrm{~Hz}$ to $1 \mathrm{MHz}$ by the $\mathrm{AC}$ impedance method, using an electrode system connected with an electrochemical workstation (CHI604). A totally dried $\mathrm{H}_{3} \mathrm{PO}_{4}$-doped rectangular piece of membrane was sandwiched between two gold electrodes in a glass cell and placed in a programmable oven to measure the temperature dependence of the conductivity. The impedance measurement was performed from $80{ }^{\circ} \mathrm{C}$ to $180{ }^{\circ} \mathrm{C}$ under anhydrous conditions. All the samples were equilibrated for at least $30 \mathrm{~min}$ at a given temperature. Repeated measurements were obtained at $10 \mathrm{~min}$ intervals until no change in conductivity was observed. The ionic conductivity of a given membrane ( $\sigma$, expressed in units of $\left.\mathrm{S} \mathrm{cm}^{-1}\right)$ was calculated from the following equation:

$$
\sigma=\frac{l}{R A}
$$

where $l$ is the distance between two stainless steel electrodes (cm), $A$ the cross-sectional area of $\mathrm{H}_{3} \mathrm{PO}_{4}$-doped membrane $\left(\mathrm{cm}^{2}\right)$ obtained from the membrane thickness multiplied by its width, and $R$ the membrane resistance value from the AC impedance data $(\Omega)$.

\section{Results and discussion}

\section{Characterization of electrolytes}

In the present study, [VBIm] $\left[\mathrm{NTf}_{2}\right]$ was synthesized and used as a hydrophobic phase in the copolymer membranes, and the synthetic procedure for [VBIm] $\left[\mathrm{NTf}_{2}\right]$ is shown in Scheme 1A. The purity and chemical structure of the synthesized [VBIm] $\left[\mathrm{NTf}_{2}\right]$ were confirmed by ${ }^{1} \mathrm{H}$ NMR measurements. Phosphoric acid doped hydrophobic ionic liquid-based composite membranes were prepared by photo polymerization in a glass mold, and the preparation of membranes is shown in Scheme 1B. Styrene and acrylonitrile were chosen to synthesize the copolymers due to their ease of processing, good mechanical properties and chemical resistance. ${ }^{33}$ The obtained composite membranes were denoted as [VBIm] $\left[\mathrm{NTf}_{2}\right]_{x}-\mathrm{VIm}_{y}$, where $x$ and $y$ indicate the weight ratio of $[\mathrm{VBIm}]\left[\mathrm{NTf}_{2}\right]$ and $N$-vinylimidazole in the membrane, respectively. As shown in Scheme 1, the prepared membrane is transparent, flexible, and can be easily cut into any desired sizes.

The chemical structures of $[\mathrm{VBIm}]\left[\mathrm{NTf}_{2}\right]_{x}$-VIm $y$ membranes without phosphoric acid were characterized by FT-IR, and the results are shown in Fig. 1. All the samples showed the absorption bands of the cyano groups $(\mathrm{C} \equiv \mathrm{N})$ at $2241 \mathrm{~cm}^{-1}$, and the absorption bands at about $2934 \mathrm{~cm}^{-1}$ arose from the stretching vibration of methylene and methyl. The absorption bands at $1400-1600 \mathrm{~cm}^{-1}$ indicated the presence of polystyrene. Absorption bands at around 1553 and $704 \mathrm{~cm}^{-1}$ were attributed to the breathing vibration of imidazole ring. The absorption bands present at 1054 and $1134 \mathrm{~cm}^{-1}$ correspond to the symmetric and asymmetric stretching vibration of sulfone groups. The absorption peaks at 1348 and $1185 \mathrm{~cm}^{-1}$ indicate the presence of $\mathrm{C}-\mathrm{F}$ groups in the membranes. The content of $[\mathrm{VBIm}]\left[\mathrm{NTf}_{2}\right]$ increases from $[\mathrm{VBIm}]\left[\mathrm{NTf}_{2}\right]_{15}-\mathrm{VIm}_{55}$ to [VBIm] $\left[\mathrm{NTf}_{2}\right]_{55}-\mathrm{VIm}_{15}$, and this trend was confirmed by a gradual increase in the intensity of the characteristic peaks of $\mathrm{C}-\mathrm{F}$ groups.

Thermal properties of $[\mathrm{VBIm}]\left[\mathrm{NTf}_{2}\right]_{x}-\mathrm{VIm}_{y}$ were characterized by thermogravimetric analysis (TGA) as shown in Fig. 2. A

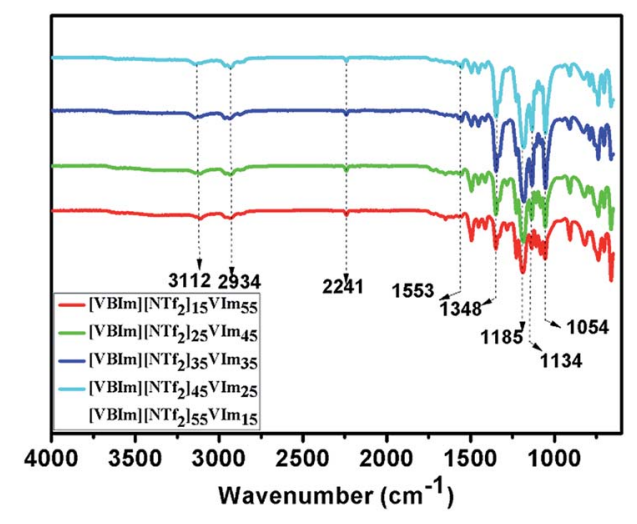

Fig. 1 FT-IR spectra of $[V B \mid m]\left[N T f_{2}\right]_{x}-V I m_{y}$. 


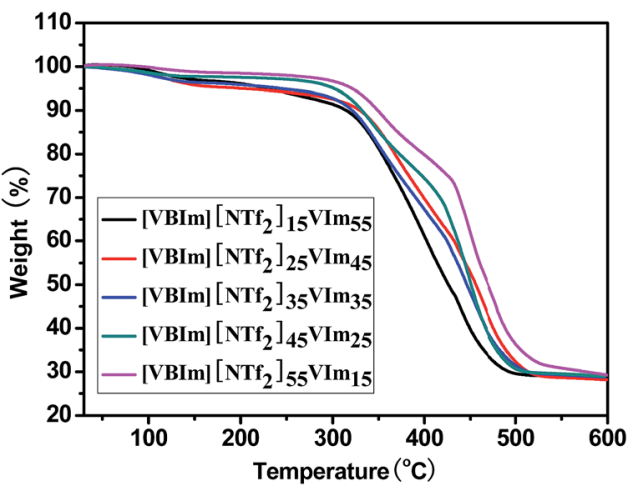

Fig. 2 TGA plots of $[\mathrm{VBIm}]\left[\mathrm{NTf}_{2}\right]_{x}-\mathrm{VIm}$ under nitrogen flow. Heating rate: $10^{\circ} \mathrm{C} \mathrm{min}^{-1}$.

small weight loss was observed at about $100{ }^{\circ} \mathrm{C}$ due to the dehydration of $[\mathrm{VBIm}]\left[\mathrm{NTf}_{2}\right]_{x}-\mathrm{VIm}_{y}$. The main weight loss stage took place at above $300{ }^{\circ} \mathrm{C}$ that can be ascribed to the mainchain degradation of $[\mathrm{VBIm}]\left[\mathrm{NTf}_{2}\right]_{x}-\mathrm{VIm}_{y}$. No noticeable decomposition was observed for $[\mathrm{VBIm}]\left[\mathrm{NTf}_{2}\right]_{x}$-VIm $\mathrm{VI}_{y}$ till $300{ }^{\circ} \mathrm{C}$, confirming that this type of hydrophobic ionic liquid-based PEMs indeed confers a high thermal stability for their applications in high temperature PEMFCs.

The $\mathrm{H}_{3} \mathrm{PO}_{4}$ uptake and swelling ratio of $[\mathrm{VBIm}]\left[\mathrm{NTf}_{2}\right]_{x}-\mathrm{VIm}_{y}$ are listed in Table 1. An imidazolium salt could be obtained from the reaction of $N$-vinylimidazole and $\mathrm{H}_{3} \mathrm{PO}_{4}$ (Scheme 1B). Generally, the $\mathrm{H}_{3} \mathrm{PO}_{4}$ uptake and swelling ratio in $\mathrm{H}_{3} \mathrm{PO}_{4}$ of the membranes decrease upon decreasing the content of $\mathrm{N}$-vinylimidazole and increasing the content of $[\mathrm{VBIm}]\left[\mathrm{NTf}_{2}\right]$ in the membranes. However, in the present study, the $\mathrm{H}_{3} \mathrm{PO}_{4}$ uptake of the membranes increases with an increase in the content of $[\mathrm{VBIm}]\left[\mathrm{NTf}_{2}\right]$, and then decreases. This is probably because of loose structure formed by the increase of the [VBIm] $\left[\mathrm{NTf}_{2}\right]$ content due to its abundant pendent imidazolium cations and bistrifluoromethanesulfonimide anion, which results in a more free volume for adopting $\mathrm{H}_{3} \mathrm{PO}_{4}$ molecules ${ }^{34}$ and this can be confirmed by the height images shown in Fig. 3A and Fig. 3C. Microscopic phase separation structure formed in the membranes can be confirmed by the AFM phase images. The darker areas represent the copolymer composed of styrene, acrylonitrile and $N$-vinylimidazole, and the brighter areas are associated with hard hydrophobic domain composed of [VBIm] [NTf $f_{2}$ (Fig. 3B and D). However, [VBIm] $\left[\mathrm{NTf}_{2}\right]$ showed poor compatibility with $\mathrm{H}_{3} \mathrm{PO}_{4}$ due to its hydrophobic nature. Addition of excess $[\mathrm{VBIm}]\left[\mathrm{NTf}_{2}\right]$ resulted in a decrease of $\mathrm{H}_{3} \mathrm{PO}_{4}$

Table 1 The $\mathrm{H}_{3} \mathrm{PO}_{4}$ uptake and swelling ratio of $[\mathrm{VBIm}]\left[\mathrm{NTf}_{2}\right]_{x}-\mathrm{VIm}$

\begin{tabular}{lcl}
\hline Membrane & $\begin{array}{l}\mathrm{H}_{3} \mathrm{PO}_{4} \text { uptake } \\
(\%)\end{array}$ & $\begin{array}{l}\text { Swelling ratio in } \\
\mathrm{H}_{3} \mathrm{PO}_{4}(\%)\end{array}$ \\
\hline$[\mathrm{VBIm}]\left[\mathrm{NTf}_{2}\right]_{15}-\mathrm{VIm}_{55}$ & 74.18 & 37 \\
{$[\mathrm{VBIm}]\left[\mathrm{NTf}_{2}\right]_{25}-\mathrm{VIm}_{45}$} & 98.10 & 49 \\
{$[\mathrm{VBIm}]\left[\mathrm{NTf}_{2}\right]_{35}-\mathrm{VIm}_{35}$} & 134.74 & 63 \\
{$[\mathrm{VBIm}]\left[\mathrm{NTf}_{2}\right]_{45}-\mathrm{VIm}_{25}$} & 107.85 & 54 \\
{$[\mathrm{VBIm}]\left[\mathrm{NTf}_{2}\right]_{55}-\mathrm{VIm}_{15}$} & 84.62 & 41
\end{tabular}

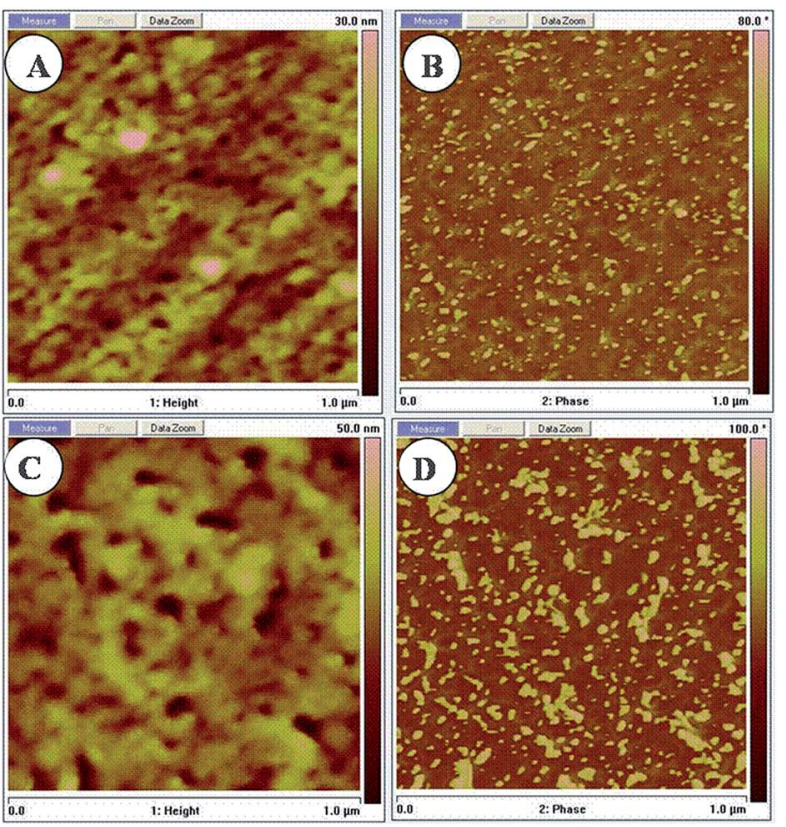

Fig. 3 AFM tapping height and phase images of $[\mathrm{VBIm}]\left[\mathrm{NTf}_{2}\right]_{15}-\mathrm{VIm} \mathrm{m}_{55}$ $(A, B)$ and $[V B I m]\left[N T f_{2}\right]_{35}-V I m_{35}(C, D)$.

uptake of the membranes, and $[\mathrm{VBIm}]\left[\mathrm{NTf}_{2}\right]_{35}$-VIm ${ }_{35}$ showed the highest $\mathrm{H}_{3} \mathrm{PO}_{4}$ uptake (134.74 wt\%) among the produced membranes. Just as expected, the change in the trends of the swelling ratio of $[\mathrm{VBIm}]\left[\mathrm{NTf}_{2}\right]_{x}-\mathrm{VIm}_{y}$ is similar to that of $\mathrm{H}_{3} \mathrm{PO}_{4}$ uptake. Therefore, the $\mathrm{H}_{3} \mathrm{PO}_{4}$ uptake and swelling ratio of the membranes could be adjusted by varying the content of [VBIm] $\left[\mathrm{NTf}_{2}\right]$ in the membranes.

The mechanical properties of $[\mathrm{VBIm}]\left[\mathrm{NTf}_{2}\right]_{x}-\mathrm{VIm}_{y}$ were measured using a universal testing machine at room temperature with a crosshead speed of $5 \mathrm{~mm} \mathrm{~min}{ }^{-1}$. Table 2 lists the tensile strength, tensile modulus and elongation at the break of [VBIm] $\left[\mathrm{NTf}_{2}\right]_{x}-\mathrm{VIm}_{y}$ membranes. The tensile strength of [VBIm] $\left[\mathrm{NTf}_{2}\right]_{x}-\mathrm{VIm}_{y}$ is in the range of $11.75-18.01 \mathrm{MPa}$, with the tensile modulus of 400-947 MPa, and the values of elongation at break of $8-24 \%$. In the present study, [VBIm] $\left[\mathrm{NTf}_{2}\right]$ acts as a hydrophobic phase and endows the membranes good mechanical properties just like the backbone of Nafion membranes. Therefore, the tensile strength and tensile modulus of membranes increase with increasing $[\mathrm{VBIm}]\left[\mathrm{NTf}_{2}\right]$ content in the membranes due to its hydrophobic nature. The results

Table 2 Mechanical properties of [VBIm] $\left[\mathrm{NTf}_{2}\right]_{x}-\mathrm{VIm}$

\begin{tabular}{lllr}
\hline & $\begin{array}{l}\text { Tensile } \\
\text { strength } \\
(\mathrm{MPa})\end{array}$ & $\begin{array}{l}\text { Tensile } \\
\text { modulus } \\
\text { Membranes }\end{array}$ & $\begin{array}{l}\text { Elongation at } \\
\text { break (\%) }\end{array}$ \\
\hline$[\mathrm{VBIm}]\left[\mathrm{NTf}_{2}\right]_{15}-\mathrm{VIm}_{55}$ & $11.75 \pm 0.3$ & $400.94 \pm 20.0$ & $8.56 \pm 1.0$ \\
{$[\mathrm{VBIm}]\left[\mathrm{NTf}_{2}\right]_{25}-\mathrm{VIm}_{45}$} & $12.82 \pm 1.1$ & $553.70 \pm 33.1$ & $13.64 \pm 0.6$ \\
{$[\mathrm{VBIm}]\left[\mathrm{NTf}_{2}\right]_{35}-\mathrm{VIm}_{35}$} & $14.44 \pm 0.5$ & $631.97 \pm 34.3$ & $24.36 \pm 0.9$ \\
{$[\mathrm{VBIm}]\left[\mathrm{NTf}_{2}\right]_{45}-\mathrm{VIm}_{25}$} & $15.30 \pm 0.8$ & $841.52 \pm 26.5$ & $17.52 \pm 0.5$ \\
{$[\mathrm{VBIm}]\left[\mathrm{NTf}_{2}\right]_{55}-\mathrm{VIm}_{15}$} & $18.01 \pm 0.4$ & $947.23 \pm 17.8$ & $10.77 \pm 1.2$
\end{tabular}




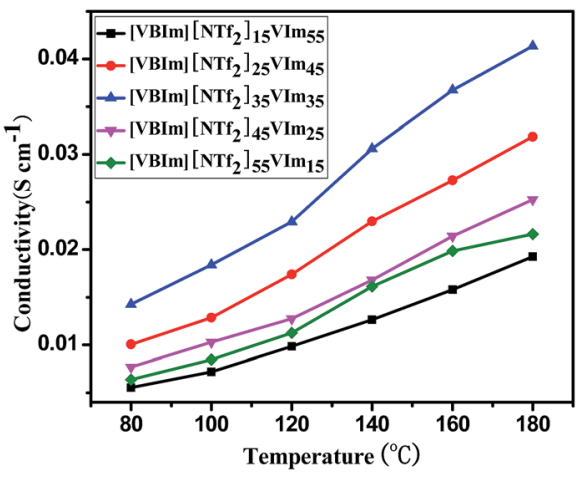

Fig. 4 Proton conductivity of $[\mathrm{VB} \mid \mathrm{m}]\left[\mathrm{NTf}_{2}\right]_{x}-\mathrm{V} I \mathrm{~m}_{y}$.

show that $[\mathrm{VBIm}]\left[\mathrm{NTf}_{2}\right]_{x}$-VIm $y$ membranes possess sufficient mechanical strength for fuel cell applications, and the mechanical properties of $[\mathrm{VBIm}]\left[\mathrm{NTf}_{2}\right]_{x}-\mathrm{VIm}_{y}$ could be adjusted easily by changing the content of $[\mathrm{VBIm}]\left[\mathrm{NTf}_{2}\right]$ in the membranes.

Proton conductivity is a key property for PEM materials. Herein, anhydrous proton conductivities of the membranes containing a variety amount of $\mathrm{H}_{3} \mathrm{PO}_{4}$ under $80-180{ }^{\circ} \mathrm{C}$ are depicted in Fig. 4, and enhancement in proton conductivity upon rising temperature has been observed for all the samples. For example, $[\mathrm{VBIm}]\left[\mathrm{NTf}_{2}\right]_{15}-\mathrm{VIm}_{55}$ shows the conductivity of $5.6 \times 10^{-3} \mathrm{~S} \mathrm{~cm}^{-1}$ at $80^{\circ} \mathrm{C}$ and the value increases to $1.9 \times 10^{-2}$ $\mathrm{S} \mathrm{cm}{ }^{-1}$ at $180{ }^{\circ} \mathrm{C}$. Similar to the $\mathrm{H}_{3} \mathrm{PO}_{4}$ uptake and swelling ratio, the conductivity of the membranes at a given temperature increased with increasing content of $[\mathrm{VBIm}]\left[\mathrm{NTf}_{2}\right]$ at first, and then decreased. No decay in proton conductivity was observed even at $180{ }^{\circ} \mathrm{C}$ for $[\mathrm{VBIm}]\left[\mathrm{NTf}_{2}\right]_{x}$-VIm ${ }_{y}$, which further confirms the excellent thermal stability of the membranes. Generally, higher $\mathrm{H}_{3} \mathrm{PO}_{4}$ uptake, leads to higher conductivity of the membranes. Among the $[\mathrm{VBIm}]\left[\mathrm{NTf}_{2}\right]_{x}-\mathrm{VIm}_{y}$ membranes, [VBIm] $\left[\mathrm{NTf}_{2}\right]_{35}-\mathrm{VIm}_{35}$ showed the highest $\mathrm{H}_{3} \mathrm{PO}_{4}$ uptake. Furthermore, a well-defined phase separation morphology was formed in [VBIm] $\left[\mathrm{NTf}_{2}\right]_{35}-\mathrm{VIm}_{35}$, which favors the transmission of proton. ${ }^{35-38}$ It is not surprising that $[\mathrm{VBIm}]\left[\mathrm{NTf}_{2}\right]_{35}-\mathrm{VIm}_{35}$ showed the highest conductivity $\left(4.14 \times 10^{-2} \mathrm{~S} \mathrm{~cm}^{-1}\right.$ at $\left.180^{\circ} \mathrm{C}\right)$.

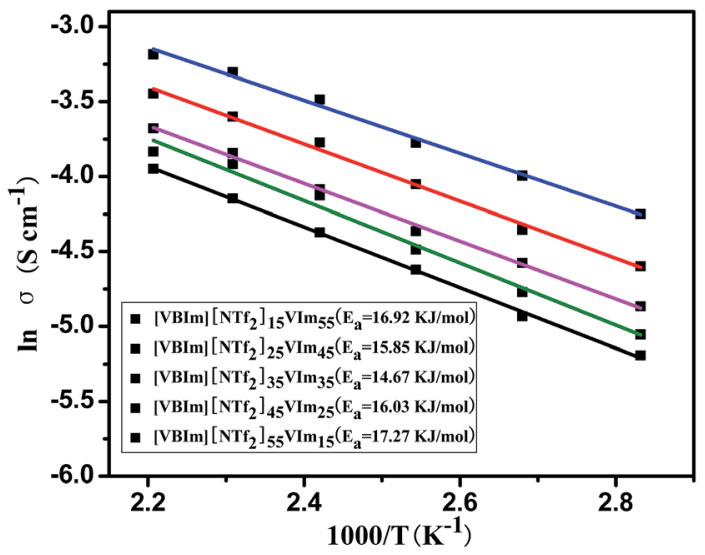

Fig. 5 Arrhenius plots for $[\mathrm{VBIm}]\left[\mathrm{NTf}_{2}\right]_{x}-\mathrm{VIm}$.
The conductivity activation energy $\left(E_{\mathrm{a}}\right)$ of $[\mathrm{VBIm}]\left[\mathrm{NTf}_{2}\right]_{x}-\mathrm{VIm}_{y}$ can be obtained from the proton conductivity of the membranes..$^{33}$ Fig. 5 displays the plots of $\ln (\sigma) v s .1000 / T$ ( $T$ is the absolute temperature) for $[\mathrm{VBIm}]\left[\mathrm{NTf}_{2}\right]_{x}-\mathrm{VIm}_{y}$. The $E_{\text {a }}$ obtained from the slope of the line ranged from 14.67 to $17.27 \mathrm{~kJ} \mathrm{~mol}^{-1}$. The changing trend of $E_{\mathrm{a}}$ values is strongly related to the $\mathrm{H}_{3} \mathrm{PO}_{4}$ uptake of membranes, and $[\mathrm{VBIm}]\left[\mathrm{NTf}_{2}\right]_{35^{-}}$ $\mathrm{VIm}_{35}$ showed the lowest $E_{\mathrm{a}}\left(14.67 \mathrm{~kJ} \mathrm{~mol}^{-1}\right)$, indicating that proton transfer needs the least energy among the produced membranes. It could be concluded that the proton transport mechanism of $[\mathrm{VBIm}]\left[\mathrm{NTf}_{2}\right]_{x}-\mathrm{VIm}_{y}$ is not changed under $80-$ $180^{\circ} \mathrm{C}$ with no change observed in the slope of the Arrhenius plot for the membranes (Fig. 5). ${ }^{29}$

\section{Conclusion}

In summary, a series of phosphoric acid doped cross-linked copolymer membranes with different hydrophobic ionic liquid contents were synthesized and characterized. The resultant hydrophobic ionic liquid-based PEMs had excellent thermal stability and high conductivity at elevated temperatures under anhydrous conditions. The introduction of proper amount of $[\mathrm{VBIm}]\left[\mathrm{NTf}_{2}\right]$ can be beneficial to increase the conductivity of PEMs. The resultant hydrophobic ionic liquidbased PEMs demonstrated great potential for proton exchange membrane fuel cell applications based on its good thermal stability, sufficient mechanical properties and high proton conductivity at high temperature. This study on hydrophobic ionic liquid-based PEMs will have an impact on further investigations of high temperature proton exchange membranes for fuel cells.

\section{Acknowledgements}

This work was supported by the National Natural Science Foundation of China (No. 51303017 and 21476031) and the Jiangsu Natural Science Foundation (BK20151187), and a project funded by the Priority Academic Program Development of Jiangsu Higher Education Institutions.

\section{Notes and references}

1 M. Gratzel, R. A. J. Janssen, D. B. Mitzi and E. H. Sargent, Nature, 2012, 488, 304-312.

2 A. F. Nogueira, J. R. Durrant and M. A. De Paoli, Adv. Mater., 2001, 13, 826-830.

3 K. Lee, J. S. Spendelow, Y. K. Choe, C. Fujimoto and Y. S. Kim, Nat. Energy, 2016, 1, 16120.

4 H. Zhang, W. Wua, J. Wang, T. Zhang, B. Shi, J. Liu and S. Cao, J. Membr. Sci., 2015, 476, 136-147.

5 G. Nawn, G. Pace, S. Lavina, K. Vezzù, E. Negro, F. Bertasi, S. Polizzi and V. Di Noto, Macromolecules, 2015, 48, 15-27.

6 V. Di Noto, E. Negro, J. Y. Sanchez and C. Iojoiu, J. Am. Chem. Soc., 2010, 132, 2183-2195.

7 A. Hagfeldt, G. Boschloo, L. Sun, L. Kloo and H. Pettersson, Chem. Rev., 2010, 110, 6595-6663. 
8 L. E. Karlsson and P. Jannasch, J. Membr. Sci., 2004, 230, 6170.

9 D. S. Kim, B. Liu and M. D. Guiver, Polymer, 2006, 47, 78717880.

10 F. Chu, B. Lin, B. Qiu, Z. Si, L. Qiu, Z. Gu, J. Ding, F. Yan and J. Lu, J. Mater. Chem., 2012, 22, 18411-18417.

11 T. Tezuka, K. Tadanaga, A. Hayashi and M. Tatsumisago, J. Am. Chem. Soc., 2006, 128, 16470-16471.

12 Suryani and Y. Liu, J. Membr. Sci., 2009, 332, 121-128.

13 M. L. Di Vona, E. Sgreccia, S. Licoccia, M. Khadhraoui, R. Denoyel and P. Knauth, Chem. Mater., 2008, 20, 43274334.

14 B. Lin, S. Cheng, L. Qiu, F. Yan, S. Shang and J. Lu, Chem. Mater., 2010, 22, 1807-1813.

15 J. Zhu, G. Zhang, K. Shao, C. Zhao, H. Li and H. Na, J. Power Sources, 2011, 196, 5803-5810.

16 K. S. Roelofs, A. Kampa, T. Hirth and T. J. Schieste, Appl. Polym. Sci., 2009, 6, 2998-3009.

17 Y. Zhou, W. Xiang, S. Chen, S. Fang, X. Zhou, J. Zhang and Y. Lin, Chem. Commun., 2009, 26, 3895-3897.

18 E. I. Santiago, R. A. Isidoro, M. A. Dresch, B. R. Matos, M. Linardi and F. C. Fonseca, Electrochim. Acta, 2009, 54, 4111-4117.

19 F. Yan, S. Yu, X. Zhang, L. Qiu, F. Chu, J. You and J. Lu, Chem. Mater., 2009, 21, 1480-1484.

20 S. Yi, F. Zhang, W. Li, C. Huang, H. Zhang and M. Pan, J. Membr. Sci., 2011, 366, 349-355.

21 S. Y. Lee, A. Ogawa, M. Kanno, H. Nakamoto, T. Yasuda and M. Watanabe, J. Am. Chem. Soc., 2010, 132, 9764-9773.

22 P. Ngamsantivongs, H. L. Lin and T. L. Yu, J. Membr. Sci., 2015, 491, 10-21.

23 F. Mack, K. Aniol, C. Ellwein, J. Kerres and R. Zeis, J. Mater. Chem. A, 2015, 3, 10864-10874.
24 G. Elden, M. Celik, G. Genc and H. Yapici, Energy, 2016, 103, 772-783.

25 M. Schuster, T. Rager, A. Noda, K. D. Kreuer and J. Maier, Fuel Cells, 2005, 5, 355-365.

26 H. Steininger, M. Schuster, K. D. Kreuer, A. Kaltbeitzel, B. Bingol, W. H. Meyer, S. Schauff, G. Brunklaus, J. Maier and H. W. Spiess, Phys. Chem. Chem. Phys., 2007, 9, 17641773.

27 H. Deligöz and M. Yılmazoğlu, J. Power Sources, 2011, 196, 3496-3502.

28 X. Li, M. Drache, X. Ke, U. Gohs and S. Beuermann, Macromol. Mater. Eng., 2016, 301, 56-64.

29 Z. H. Si, F. L. Gu, J. N. Guo and F. Yan, J. Polym. Sci., Part B: Polym. Phys., 2013, 51, 1311-1317.

30 J. Fang, X. Lin, D. Cai, N. He and J. Zhao, J. Membr. Sci., 2016, 502, 29-36.

31 E. A. Weiber and P. Jannasch, ChemSusChem, 2014, 7, 26212630.

32 B. Lin, H. Shang, F. Chu, Y. Ren, N. Yuan, B. Jia, S. Zhang, Y. Wei, X. Yu and J. Ding, Electrochim. Acta, 2014, 134, 209-214.

33 H. Diao, F. Yan, L. Qiu, J. Lu, X. Lu, B. Lin, Q. Li, S. Shang, W. Liu and J. Liu, Macromolecules, 2010, 43, 6398-6405.

34 Y. Yang, N. Sun and L. Q. Zheng, RSC. Adv., 2016, 6, 5889058897.

35 H. Zhang, W. Wu, Y. Li, Y. Liu, J. Wang, B. Zhang and J. Liu, J. Power Sources, 2015, 279, 667-677.

$36 \mathrm{~W}$. Wu, Y. Li, P. Chen, J. Liu, J. Wang and H. Zhang, ACS Appl. Mater. Interfaces, 2016, 8, 588-599.

37 S. Maity, S. Singha and T. Jana, Polymer, 2015, 66, 76-85.

38 M. W. Schulze, L. D. Mcintosh, M. A. Hillmyer and T. P. Lodge, Nano Lett., 2014, 14, 122-126. 